\title{
Ефективність мікрогранулярної форми 5-аміносаліцилової кислоти в післяопераційному періоді ускладненої хвороби Крона
}

\author{
V. V. MISHCHUK \\ Ivano-Frankivsk National Medical University
}

\section{EFFICIENCY OF MICROGRANULAR FORM OF 5-AMINOSALICYLIC ACID IN THE POSTOPERATIVE PERIOD OF COMPLICATED CROHN'S DISEASE}

\begin{abstract}
Сучасні концепції хірургічного лікування хвороби Крона спрямовані на виконання економних резекцій кишки, застосування малоінвазивних методик. Водночас операція не завжди може попередити рецидив та прогресування хвороби і в післяопераційному періоді необхідна подальша медикаментозна терапія. Із 35 хворих у 14 проведено лапароскопічну санацію і дренування черевної порожнини, у 5 - секторальну резекцію ураженого фрагмента тонкої кишки з формуванням ентеро-ентероанастомозу, у 13 - резекцію висхідного відділу товстої кишки та метра тонкої з формуванням ентероентероанастомозу, ще у 3-х - лапароскопічну резекцію низхідного відділу товстої кишки. У післяопераційному періоді усіх цих хворих поділено на дві групи, одна з яких (18 хворих) на фоні дезінтоксикаційної і антибіотикотерапії отримувала мікрогранульований препарат 5-аміносаліцилової кислоти (пентаса по 2000 мг всередину та 1000 мг у свічках), а інша (17 хворих) тільки дезінтоксикаційну та антибіотикотерапію. Встановлено, що у хворих на ускладнену хворобу Крона, які отримували пентасу, на 18,36 \% випадків частіше зникав біль у животі, на 2-3 дні раніше нормалізувалась температура тіла та на 2 дні раніше наставала нормалізація випорожнень. Під впливом пентаси у прооперованих хворих достовірно зменшувався рівень C-реактивного протеїну, гістаміну та зростала концентрація ендотеліального моноцитарного протеїну (ЕМАП-ІІ) як протизапального фактора порівняно з пацієнтами, які в післяопераційному періоді не отримували патогенетичної терапії.
\end{abstract}

The modern concept of surgical treatment of Crohn's disease head towards the implementation of economical resection of bowel, the use of minimal-invasive techniques. At the same time, the operation can not always prevent the recurrence and progression of disease and there is a need of further medical therapy in the postoperative period. Among 35 patients in 14 of them underwent laparoscopic sanitation and drainage of the abdominal cavity, 5 - sectoral resection of modified fragment of the small intestine with the formation of entero-enteroanastomosis, 13 - resection of the ascending colon and a meter of the small intestine with the formation of entero-enteroanastomosis, 3 - laparoscopic resection of the descending part of the colon. In the postoperative period all of these patients were divided into 2 groups, one of which (18 patients) on the background of detoxification and antibiotic therapy took microgranular form of 5-aminosalicylic acid (Pentasa $2000 \mathrm{mg}$ orally and $1000 \mathrm{mg}$ in suppositories) and the other (17 patients) only detoxification and antibiotic therapy. There were found that in patients with Crohn's disease treated with Pentase pain disappeared in $\mathbf{1 8 . 3 6} \%$ more of cases, body temperature normalized in 2-3 days earlier, normalization of stool begun in 2 days earlier comparing to another group. Under the influence of Pentase in operated patients level of C-reactive protein and histamine concentration significantly reduced, and monocytic endothelial protein (EMAP-II) - increased as an antiinflammatory factor in comparison to patients, who did not receive pathogenetic therapy in the postoperative period.

Постановка проблеми і аналіз останніх досліджень та публікацій. Хвороба Крона (ХK) - хронічне рецидивне захворювання шлунково-кишкового тракту нез'ясованої етіології, що проявляється трансмуральним сегментарним гранулематозним запаленням переважно тонкої i верхніх відділів товстої кишок, з розвитком місцевих і системних ускладнень [17].

Для визначення локалізації ураження шлунково-кишкового тракту при ХК використовується
Монреальська (2005) класифікація, яка передбачає виділення термінального ілеїту, ілеоколіту, коліту проксимальних відділів товстої кишки і верхніх відділів шлунково-кишкового тракту, що можуть доповнювати будь-яку з трьох його форм [22]. Залежно від фенотипового варіанта виділяють пенетрувальну, стриктурну і запальну (нестриктурну, непенетрувальну) форми [18]. У значної частини пацієнтів протягом перебігу хвороби з'являються ускладнення та показання до операційного ліку- 
вання, особливо, враховуючи переважання після 10 років тривалості хвороби пенетрувальних та стриктурних варіантів перебігу [12, 19].

У багатьох країнах світу відмічається тенденція до зростання захворюваності на хворобу Крона $[14,16]$. Дані ж щодо поширеності ХК у різних країнах світу неоднозначні і вказують на частоту захворювання від 10 до 150 випадків на 100 тис. населення, а такі розбіжності зумовлені труднощами діагностики захворювання, особливо до появи ускладнень, нерідко неспецифічністю клінічних проявів, відсутністю конкретних інструментальних та лабораторних методів дослідження 3 метою його діагностики [10].

Для диференційної діагностики з іншими патологічними станами з боку органів черевної порожнини, своєчасного виявлення ускладнень нерідко застосовуються ультразвукове та рентгенологічне дослідження з пасажем барієвої суміші, комп’ютерна магнітно-резонансна томографія, фістулографія при підозрі на міжкишкові чи кишковозаочеревинні нориці, капсульна та балонна ентероколоноскопія [7, 17].

При хворобі Крона нерідкими є ускладнення, серед яких найбільш часто зустрічаються внутрішні нориці, що з'єднують між собою петлі кишки, які частіше локалізуються у здухвинній кишці при регіональному ілеїті та відмічаються, за даними різних авторів, від 10-17 \% до 30-45 \%, тоді як зовнішні нориці - лише у 1 \% випадків [6]. Особливо важко діагностуються перфорації у хворих, що тривало приймали кортикостероїди, під впливом яких маскуються специфічні ознаки, внаслідок чого створюється небезпека пропустити дане ускладнення і несвоєчасно виконати операційне втручання [11]. Крім того, операційного лікування вимагають стриктури ілеоцекального кута 3 частими симптомами кишкової непрохідності, що зберігаються протягом декількох тижнів на фоні адекватної протизапальної терапії.

Операційне лікування з одномоментним формуванням міжкишкового анастомозу показане при післяободовій локалізації процесу, на тлі високого ураження тонкої кишки і гострого перебігу вказаної патології, а також при хронічному перебігу і наявності рубцевих стриктур [4, 13]. Сучасні ж концепції хірургічного лікування хвороби Крона спрямовані на виконання економних резекцій кишки, застосування малоінвазивних методик та органозберігаючих операцій $[5,13]$. Вірогідність операційного лікування хвороби Крона зростає при збільшенні тривалості анамнезу, а частка випадків хірургічного лікування при п'ятирічному анамнезі хвороби становить $40 \%$, при десятирічному $70 \%$, а після 20 років тривалості хвороби оперуються 80-90 \% хворих [8]. Разом з тим операція не може попередити рецидив та прогресування хвороби і вимагає подальшої медикаментозної терапії [15]. У великому популяційному дослідженні, на значній когорті хворих, при використанні таких патогенетичних середників, як тіопурини і блокатори фактора некрозу пухлин, поряд з препаратами 5-аміносаліцилової кислоти попередження частоти ускладнень не встановлено [20, 21].

Мета роботи: вивчити ефективність продовження терапії препаратами 5-аміносаліцилової кислоти (пентаса) для патогенетичної терапії в післяопераційному періоді.

Матеріали і методи. У дослідження включено 35 хворих на хворобу Крона, з яких у 19 інтраопераційно встановленой термінальний ілеїт, ускладнений норицями тонкої кишки, а ще в 14 ураження проксимального відділу товстої кишки, 3 яких у 8 воно ускладнилось кишковими норицями, а у 6 - кишковою непрохідністю внаслідок вираженого гранулематозного процесу. Ще у 2-х хворих коліт перебігав у вигляді первинно туморозної форми та локалізувався в низхідному відділі товстої кишки. Усім хворим з ускладненими формами хвороби Крона проведено операційне втручання, види якого вказано в таблиці 1.

3 метою діагностики ускладнених форм хвороби Крона використовували ультразвукове дослідження органів черевної порожнини та її оглядову рентгенографію, фістулографію, пасаж барієвої суміші по кишечнику, а у 8 випадках комп’ютерну томографію органів черевної порожнини. У післяопераційному періоді усіх хворих поділено на дві групи, одній з яких (17 про-

Таблиця 1. Види операційних втручань, виконаних при ускладненнях хвороби Крона

\begin{tabular}{||l|c||}
\hline \hline \multicolumn{1}{|c||}{ Назва операції } & Кількість хворих \\
\hline Лапароскопічна санація і дренування черевної порожнини дезмістином & 14 \\
\hline Секторальна резекція відрізка тонкої кишки з формуванням ентеро-ентероанастомозу & 5 \\
\hline $\begin{array}{l}\text { Резекція висхідного відділу товстої кишки та 1 м тонкої кишки з формуванням ентеро- } \\
\text { ентероанастомозу, санація черевної порожнини дезмістином }\end{array}$ & 13 \\
\hline $\begin{array}{l}\text { Лапароскопічна резекція низхідного відділу товстої кишки з накладанням первинного } \\
\text { апаратного анастомозу кінець в кінець }\end{array}$ & 3 \\
\hline \hline
\end{tabular}


оперованих) проводили дезінтоксикаційну та антибіотикотерапію, а другій (18 чоловік) зразу призначали препарат 5-аміносаліцилової кислоти (пентаса, Pharbib Pharma, DRU) по 2000 мг всередину та по 1000 мг у свічках в пряму кишку. Особливістю пентаси є те, що 30-50 \% прийнятої всередину дози всмоктується в тонкій кишці і там же вона піддається ацетилюванню, не впливаючи на рівень ентеробактерій. Серед механізмів дії пентаси провідними є інгібування синтезу прозапальних простагландинів, гальмування дегрануляції нейтрофілів, зменшення утворення лейкотрієнів і цитокінів, здатних підтримувати запальний процес у стінці тонкої кишки, а її мікрогранулярна структура забезпечує місцеву лікувальну дію протягом 3-4 год і не залежить від рН середовища. Водночас питання ефективності її застосування при тонкокишковій локалізації хвороби Крона вимагає подальшого вивчення [3]. Одразу після операції та через 1 місяць у хворих обох груп визначали рівень гістаміну та протизапального ендотеліально-моноцитарного активуючого поліпептиду II (ЕМАП-II) імуноферментними методами з використанням наборів "Histamine Elisa KIT" (Німеччина) та EMAP-II ELISA - test KIT фірми BIOSOURSE EUROPE SA відповідно. Також з метою оцінки ступеня активності запального процесу в організмі усім обстеженим до та через місяць після комплексного лікування визначали рівень С-реактивного протеїну за допомогою реактивів фірми HUMAN і виражали у мг/мл. Статистичну обробку отриманих результатів проводили за допомогою комп’ютерної програми STATISTIKA-8 та пакета статистичних функцій програми “Microsoft Excels” на персональному комп’ютері з обчисленням середньоарифметичної величини “М”, помилки середньоарифметичної “m”, вірогідності різниці двох середньоарифметичних “р”.

Результати досліджень та їх обговорення. Однією із серйозних проблем хвороби Крона після операційного втручання є її рецидив, а за допомогою хірургічного лікування в ряді випадків можна досягнути лише тимчасового поліпшення. Тому все частіше стоїть проблема подальшої консервативної терапії [17]. Після завершення операційного лікування біль у правій половині живота ниючого характеру залишався у 29,47 \% хворих першої групи і лише у 11,11 \% - другої, які отримували пентасу у вигляді комбінованої терапії. Температура тіла, що рівнялась у післяопераційному періоді в середньому $(38,1 \pm 0,2){ }^{\circ} \mathrm{C}$, нормалізувалась на 3-й день після операції у пацієнтів другої та лише на 5-6-й день в обстежених першої групи. Кількість лейкоцитів у периферичній крові у хворих, оперованих з приводу хворо- би Крона, що отримували препарат 5-аміносаліцилової кислоти, на 5-й день лікування зменшилась 3 13,3 $\pm 1,3 \times 10^{9}$ /л до 8,2 $\pm 0,5 \times 10^{9} / л(\mathrm{p}<0,05) \mathrm{i}$ дещо менш виражено у тих обстежених, яким препарат даної групи не призначали (з 12,2士0,4×10\%/л до $\left.9,7 \pm 0,5 \times 10^{9} / л\right)$. Відновлення самостійного випорожнення після операції настало через $(6,2 \pm 0,5)$ дня у пацієнтів першої групи та через $(4,2 \pm 0,2)$ дня - в обстежених другої. На поліпшення якості життя хворих на хворобу Крона при адекватній післяопераційній тактиці лікування вказують і інші дослідники [2].

Вивчення динаміки рівня С-реактивного білка в сироватці крові у хворих через 30 діб після операційного лікування хвороби Крона і приймання ними пентаси свідчить про його зниження з $(15,78 \pm 1,02)$ до $(10,9 \pm 0,65)$ мг/мл, тоді як в обстежених, яким у післяопераційному періоді препарат 5-аміносаліцилової кислоти не призначали, його рівень достовірно не змінився $((17,7 \pm 0,75)$ мг/мл - до і $(17,35 \pm 0,85)$ мг/ мл на 30-й день після операції). Концентрація гістаміну в сироватці крові у хворих першої групи знизилась із $(5,97 \pm 0,34)$ до $(2,33 \pm 0,22)$ нг/мл $(\mathrm{p}<0,05)$, тоді як в обстежених, які в післяопераційному періоді не отримували патогенетичної терапії, рівень даного маркера запалення знижувався не так виражено (з $(4,72 \pm 0,23)$ до $(3,72 \pm 0,20)$ нг/мл). Отримані дані підтверджують думку деяких авторів про необхідність посилення терапії хвороби Крона в післяопераційному періоді, особливо пацієнтів із групи високого ризику, в яких мала місце резекція кишки, а також тих, у кого відмічалися рецидивуючі нориці та утримувався запальний процес у залишених відділах кишечника [9]. У прооперованих хворих на хворобу Крона, які отримували патогенетичну терапію, встановлено підвищення в крові рівня протизапального цитокіну ЕМАП-ІІ з $(0,44 \pm 0,02)$ до $(0,73 \pm 0,05)$ нг/мл $(p<0,05)$. Як відомо, ЕМАП-II має протизапальні та антипухлинні властивості, бере участь в ангіогенезі, індукує апоптоз клітин ендотелію та десквамованих ентероцитів через забезпечення підвищеної чутливості мікроциркуляторного русла до фактора некрозу пухлин [1]. У хворих на хворобу Крона, яким у післяопераційному періоді пентасу не призначали, рівень ЕМАП-ІІ мав тенденцію до зростання (з $(0,42 \pm 0,03)$ до $(0,49 \pm 0,02)$ нг/мл).

Висновок. Препарат 5-аміносаліцилової кислоти - пентаса у хворих на ускладнену хворобу Крона може призначатися в післяопераційному періоді з метою зменшення запального процесу в організмі, про що свідчить зниження маркерів запалення, як загальної кількості лейкоцитів, рівня C-реактивного протеїну, гістаміну, так і підвищення концентрації протизапального цитокіну. 


\section{З ДОСВІДУ РОБОТИ}

\section{СПИСОК ЛІТЕРАТУРИ}

1. Возианов А. Ф. Влияние препаратов рекомбинантного белка ЕМАР-II на рост, гистологические и гистохимические характеристики гетеротрансплантатов рака простаты человека / А. Ф. Возианов, А. Г. Резников, А. И. Корнелюк // Журнал АМН України. - 2008. - Т. 14, № 4. - С. 719-729.

2. Голышева С. В. О качестве жизни больных язвенным колитом и болезнью Крона после хирургического лечения / С. В. Голышева, П. С. Ветшев, А. Г. Григорьева // Вестник национального медико-хирургического центра им. Н. И. Пирогова. - 2013. - Т. 8, № 2. - С. 97-101.

3. Гриневич В. Б. Механизмы эффективности базисной терапии воспалительных заболеваний кишечника препаратами 5-аминосалициловой кислоты / В. Б. Гриневич, А. М. Першко, И. В. Губонина // Эффективная фармакотерапия. Гастроэнтерология. - 2011. - № 1 /go meil ru /search. $\mathrm{rf}=7993 \mathrm{efm}=18 \mathrm{tg}$

4. Профілактика та інтенсивна терапія гнійно-септичних ускладнень при хірургічному лікуванні хворих на хворобу Крона / Ф. І. Гюльмамедов, П. Ф. Гюльмамедов, О. П. Кухто [та ін.] // Шпитальна хірургія. - 2004. - № 4. - С. 111-114. 5. Кухто О. П. Обгрунтування особливостей хірургічного лікування хвороби Крона / О. П. Кухто : автореф. дис. на здобуття наук. ступеня канд. мед. наук. - 2008. - 19 с.

6. Неспецифические воспалительные заболевания кишечника / под ред. Г. И. Воробьева, И. Л. Халифа. - М. : Миклош, 2008. - 400 с.

7. Ендоскопічне дослідження при хворобі Крона / В. І. Русин, С. М. Чобей, I. І. Шкріба, А. В. Сочка // Актуальні проблеми сучасної медицини: Вісник української медичної стоматологічної академії. - 2014. - № 2 (46), Т. 14. - С. 85-89.

8. Секачёва М. И. Комплексный поход к лечению воспалительных заболеваний кишечника / М. И. Секачёва, П. В. Царьков // Клинические перспективы гастроэнтерологии, гепатологии. - 2007. - № 6. - С. 17-22.

9. Ситкин С. И. Воспалительные заболевания кишечника: пути повышения эффективности терапии и послеоперационное ведение больных / С. И. Ситкин, В. Ю. Голофеевский, Т. В. Габрусская // Сучасна гастроентерологія. - 2009. - № 2 (46). - C. 96-100.

10. Ставцев Д. С. Значение иммуногенетических факторов в развитии болезни Крона / Д. С. Ставцев, Т. А. Астрелина, О. В. Князев, Т. В. Пухликова // РЖГГК. - 2015. - № 3. C. 70-77.

11. Филипс Р. К. С. Колоректальная хирургия / под ред.
Г. И. Воробьева. - М. : ГЭОТАР-Медиа. - 2009. - 352 с.

12. Современные аспекты этиопатогенеза, диагностики и лечения болезни Крона (научный обзор) / В. В. Хацко, А. М. Дудин, С. В. Межаков [и др.] // Ukrainian Journal of Surgery. - 2012. - № 4 (19). - С. 133-136.

13. Щербакова О. В. Практические рекомендации по хирургическому лечению болезни Крона у детей / О. В. Щербакова // Экспериментальная и клиническая гастроэнтерология. 2015. - № 1 (113). - С. 78-83.

14. Primary sclerosing cholangitis, Crohn's disease and HLA-B27 in black South African women / O. C. Buchel, F. J. Bosch, Janse van Rensburg [et al.] // Acta Gastro-enterologica Belgica. - 2012. - № 75 (4). - P. 454-457.

15. Review article: the natural history of postoperative Crohn's disease recurrence / A. Buisson, J. B. Chevaux, P. B. Allen [et al.] // Aliment Pharmacol Ther. - 2012. - № 35(6). - P. 625-633. 16. Clinical prognostic factors for disabling Crohn's disease: a systematic review and meta-analysis / C. C. Dias, P. P. Rodrigues, A. da Costa-Pereira, F. Magro // World journal of gastroenterology. - 2013. - Vol. 19, Issue 24. - P. 3866-3871.

17. Didnass A. For the European Crohn's Colitis Organisation - ECCO. The second European evidence based consensus on the diagnostic and management of Crohn's disease: current management / A. Didnass, G. Van Assche, J. Lindsay // JCC. - 2010. Vol. 4. - P. 28-62.

18. Eugene C. The second European evidence-based consensus on the diagnosis and management of Crohn's disease / C. Eugene // Clin. Res. Hepatol. Gastroenterol. - 2011. - № 35 (5). - P. 340 343.

19. Кайзер Андреас. Колоректальная хирургия ; пер. с англ. / под ред. Ю. А. Шелыгина. - М. : Издательство Панфилова; БИНОМ, 2001. - 751 с.

20. Lochs H. Prophylaxis of postoperative relapse in Crohn's disease with mesalamine: European Cooperative Crohn's Disease Study VI / H. Lochs, M. Mayer, W. E. Fleig // Gastroenterology. - 2000. - № 118 (2). - P. 264-273.

21. Changes in medical treatment and surgery rates in inflammatory bowel disease: a nationwide cohort study 1979-2011/ C. Rungoe, E. Langholz, M. Andersson [et al] // Gut. - 2014. № 63 (10). - P. 1607-1616.

22. The second European evidence-based Consensus on the diagnosis and management of Crohn's disease: special situations / Gert Van Assche, Axel Dignass, Walter Reinisch [et al.] // Journal of Crohn's and Colitis. - 2010. - Vol. 4. Issue 1. - P. 63-101. 